\title{
Impacts of land cover change on climate trend in Padang Indonesia
}

\author{
Dedi Hermon
}

Received: 11052014 / Accepted: 0109 2014 / Published online: 31122014

(๑) 2014 Faculty of Geography UGM and The Indonesian Geographers Association

\begin{abstract}
The purpose of this study was to analyze the trend of climate change through changes in the elements of Green House Gases (GHGs), includes the trend of $\mathrm{CO} 2, \mathrm{~N} 2 \mathrm{O}$, and $\mathrm{CH} 4$. The change of the extreme rainfall and temperature indices due to land cover change into developed area in Padang. Identification and analysis trends of climate change and extreme climatic events were analyzed by using RclimDex the Expert Team for Climate Change Detection and Indices (ETCCDMI) technique. Where as the analysis and interpretation of land cover changes into developed area used Landsat TM 5 and Landsat 19857 ETM + of 2011 by ERDAS 9.2 GIS with the supervised classification method and GIS Matrix. The results of the study provide informations of land cover changes into developed area at forest land $(11,758.9$ ha), shrub (3,337.3 ha), rice fields (5,977.1 ha), and garden (5,872.4 ha). It has an implication on increasing of the elements of GHGs concentration such as CO2 (14,1 ppm), N2O (5,4 ppb) and CH4 (24,8 ppb). This condition lead to an extreme temperature and presipitation indexs trends in Padang.
\end{abstract}

Keywords: Climate Change; Green House Gases; Land Cover Changes

\begin{abstract}
Abstrak Tujuan penelitian ini adalah menganalisis trend perubahan iklim melalui perubahan unsur-unsur Gas Rumah kaca (GRK) yang meliputi trend $\mathrm{CO} 2, \mathrm{~N} 2 \mathrm{O}$, dan $\mathrm{CH} 4$, serta indeks temperatur dan curah hujan ekstrim akibat perubahan tutupan lahan menjadi lahan terbangun di Kota Padang. Identifikasi dan analisis trend perubahan iklim dan kejadiankejadian iklim ekstrim di analisis dengan menggunakan metode RclimDex dengan teknik Expert Team for Climate Change Detection and Indices (ETCCDMI), sedangkan analisis perubahan tutupan lahan menjadi lahan terbangun dilakukan dengan interpretasi Citra Landsat TM+5 tahun 1985 dan Citra Landsat ETM+7 tahun 2011 dengan GIS ERDAS 9.2 dengan metode supervised classification dan GIS Matrix. Hasil penelitian memberikan informasi perubahan tutupan lahan menjadi lahan terbangun yang cukup ekstrim terjadi pada lahan hutan (11.758,9 ha), semak (3.337,3 ha), sawah (5.977,1 ha), dan kebun (5.872,4 ha). Kondisi ini mengakibatkan trend yang meningkat dari CO2 sebesar 14,1 ppm, N2O meningkat sebesar 5,4 ppb, dan CH4 meningkat sebesar 24,8 ppb. Hal ini secara langsung mengakibatkan terjadinya trend indeks temperatur ekstrim dan curah hujan ekstrim di Kota Padang.
\end{abstract}

Kata kunci: Perubahan Iklim, Gas Rumah Kaca, Perubahan Tutupan Lahan

\section{Introduction}

Land cover change is an urban development phenomenon that is difficult to solve. This is due to the urban development which directly change natural land functions. In line with the urban development caused the pressure on forest land conversion into developed area. The land cover changes will lead to the increasing of $\mathrm{CO}_{2}$ concentration in the atmosphere. The changes in agricultural and farm land into developed area will produce an increasing trend of $\mathrm{N}_{2} \mathrm{O}$ and $\mathrm{NH}_{4}$. That would affect the changes of climatic conditions in the region directly [Hermon, 2012a]. $\mathrm{CO}_{2}, \mathrm{~N}_{2} \mathrm{O}$, and $\mathrm{NH}_{4}$ are included in green house gas (GHG) which naturally can adsorb the heat radiation in the atmosphere. The change in GHGs concentration will impact unstable

Dedi Hermon

Geography Department and Graduate Programe of Padang State University

Email: dihermon006@gmail.com climatic conditions both on extreme temperature and rainfall. GHG emissions have been increasing due to the increased of fossil fuels (FF) consumption since the industrial revolution in the mid 1980s. In the last decade, $\mathrm{CH}_{4}$ emissions have declined by 22 million tons/ year from 37 million tons/year in the previous decade and $\mathrm{N}_{2} \mathrm{O}$ emissions also decreased slightly from 3,9 to 3.8 million tons/year. The $\mathrm{CO}_{2}$ emissions increased by more than double from 1.400 million tons/year to 2.900 million tones/year. It had an implication on temperature rising by $0.50 \mathrm{C}^{\circ}$ compare to pre industrial. In the long term, earth temperature will tend to be higher than the current temperature [IPCC, 2001; Hermon, 2010].

Padang is the capital city of West Sumatra Province. that has a flat to hilly relief in general, primary forest located on the eastern and southern city. It continues over the time. Land cover change into developed area covered 3,044.20 ha in 1980 and increased to 8,288.28 
ha in $1995,12,444.21$ ha in 2005 compared to 69,496 ha of Padang area [BPS Padang, 1981; BPS Padang, 1995; BPS Padang, 2006]. Land cover changes into developed area generally occur in the Lubuk Kilangan, Bungus Teluk Kabung, Koto Tangah, and Padang Selatan district. Those are belong to the hills with forest vegetation [Hermon, 2009; Hermon, 2012a; Hermon, $2012 \mathrm{~b}$ ]. The objectives of this study was is to analyze the climate trend caused by land cover changes in Padang.

\section{The Methods}

According to Zain [2002], Hermon [2009], and Hermon [2012b], the dynamics of land cover changes into developed area by interpretation of Landsat TM + 5 (1985) and Landsat ETM + 7 (2011) using ERDAS 9.2 as analysis tools. The analysis of land cover classification used supervised classification techniques on each images. This formulated six patterns of landcover, ie: (1) forest, (2) garden, (3) shrub, (4) open land, (5) paddy field, and (6) developed area. The analysis of area change (ha) for each land cover in 1985 and 2011 used ERDAS 8.6 and tools Interpreter (GIS Analysis-Matrix). Rclimdex with Expert Team for Climate Change Detection and Indices (ETCCDMI) technique had used for climate change and climatic extreme events.

\section{Result and Discussion}

The result of Landsat $5 \mathrm{TM}+$ (1985) and Landsat ETM +7 (2011) shows that land cover changes into developed area had an increasing trend. The Increasing trend of land cover change into developed land generally occurs in the eastern part of Padang. The area was converted from forest, gardens, shrubs, and rice paddies into developed area (Table 1).

Forest land, shrub, paddy field and mixed garden had changed into developed area. The change of forest land into developed area during 1985 - 2011 reached $11.758,9$ ha while paddy field changes into-developed land area as much as 5.977,1 ha. The changes of garden into developed area was $5.872,4$ ha and shrub land changes is $3.337,3$ ha (Figure 1).

The land cover changes leads to increading trend of GHG concentration for $\mathrm{CO}_{2}, \mathrm{~N}_{2} \mathrm{O}$, and $\mathrm{NH}_{4}$. It will impact the change in temperature and rainfall patterns in Padang. The concentrate of $\mathrm{CO}_{2}, \mathrm{~N}_{2} \mathrm{O}$, and $\mathrm{NH}_{4}$ from 1985 to 2011 showed an increasing trend. The concentrate of $\mathrm{CO}_{2}$ increased by $14.1 \mathrm{ppm}, \mathrm{N}_{2} \mathrm{O}$ increased by $5.4 \mathrm{ppb}$, and $\mathrm{CH} 4$ increased by $24.8 \mathrm{ppb}$. Nahas and Setiawan [2009] explained that the increase of $\mathrm{CO}_{2}$ concentrate in the air causes the increase of radiative forcing. The avarage of $\mathrm{CO}_{2}$ radiative forcing was $0.04 \pm 1.634 \mathrm{Wm}^{-2}$, radiative forcing of $\mathrm{CH}_{4}$ was $0.509 \pm 0.003 \mathrm{Wm}^{-2}$, and radiative forcing of $\mathrm{N}_{2} \mathrm{O}$ was $0.168 \pm 0.005 \mathrm{Wm}^{-2}$.

Table 1. The Land Cover Area in 1985 and 2011

\begin{tabular}{llrr}
\hline \multirow{2}{*}{ No } & Type of Land Cover & \multicolumn{2}{c}{ Area (ha) } \\
\cline { 3 - 4 } & & 1985 & 2011 \\
\hline 1 & Developed Area & $3,157.0$ & $28,573.2$ \\
2 & Open Land & 513.4 & $1,709.9$ \\
3 & Shrub & $4,901.6$ & $1,917.5$ \\
4 & Mixed Garden & $13,767.2$ & $7,539.7$ \\
5 & Forest & $40,879.5$ & $29,375.7$ \\
6 & Paddy Field & $5,897.3$ & $1,997.5$ \\
7 & River and Sea & 380.0 & 380.0 \\
\hline & Total & $69,496.0$ & $69,496.0$ \\
\hline
\end{tabular}

Source: Result of GIS Matrix Analysis of Landsat TM+5 (1985) and ETM+7 (2011) using ERDAS 9.2 (2013)

An increase of $\mathrm{CO}_{2}$ concentration in Padang was generated due to conversion of large area of forest into developed area. This conditions also supported by shrub and garden which converted into developed area due to the urgent needs of community settlements and public facilities. Carbon stock from forest land, shrub

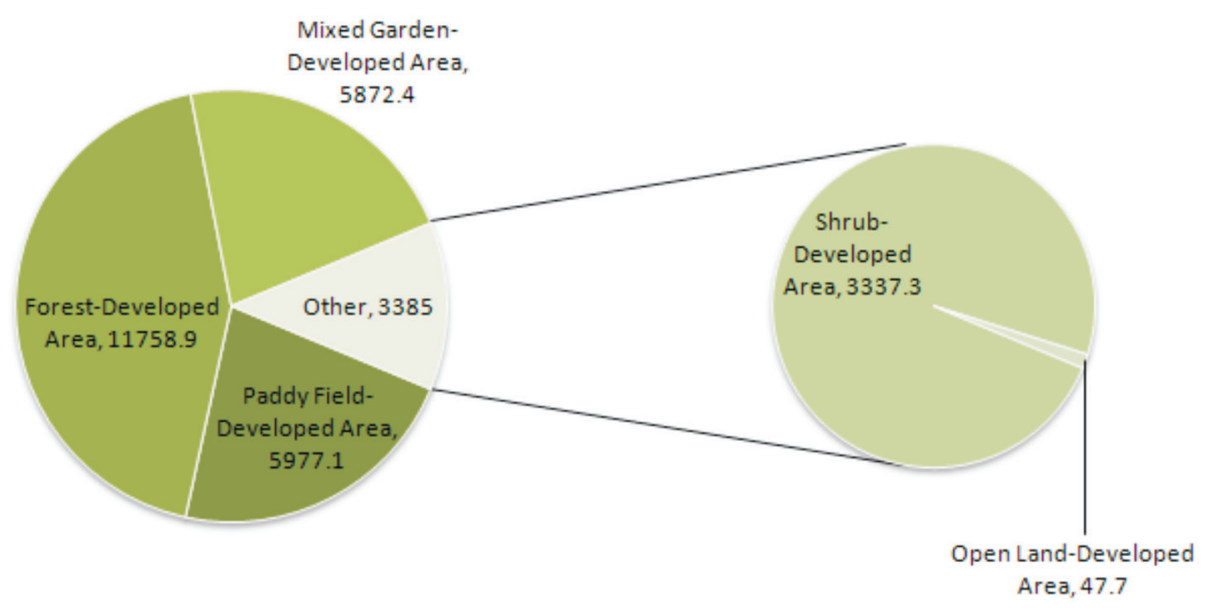

Figure 1. Land Cover Change into Developed Area (ha) in Padang from 1985 - 2011 


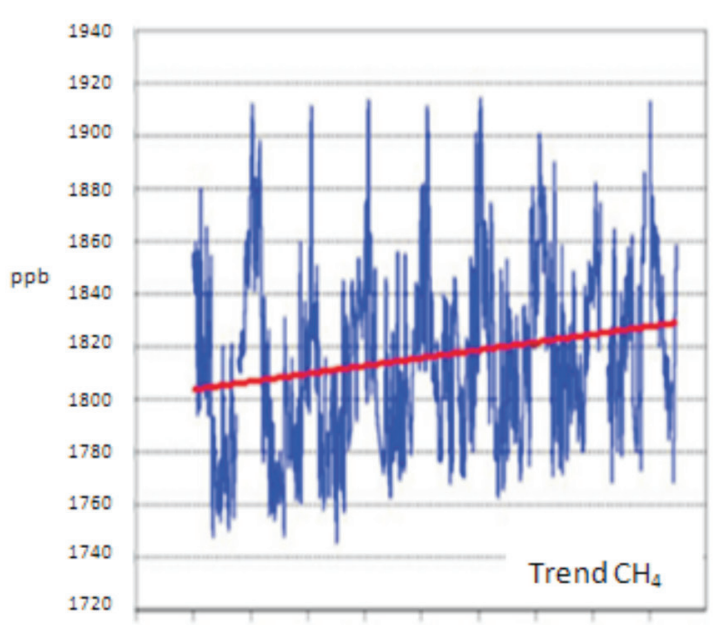

$1982198519881991 \quad 1994199720002003200620092012$

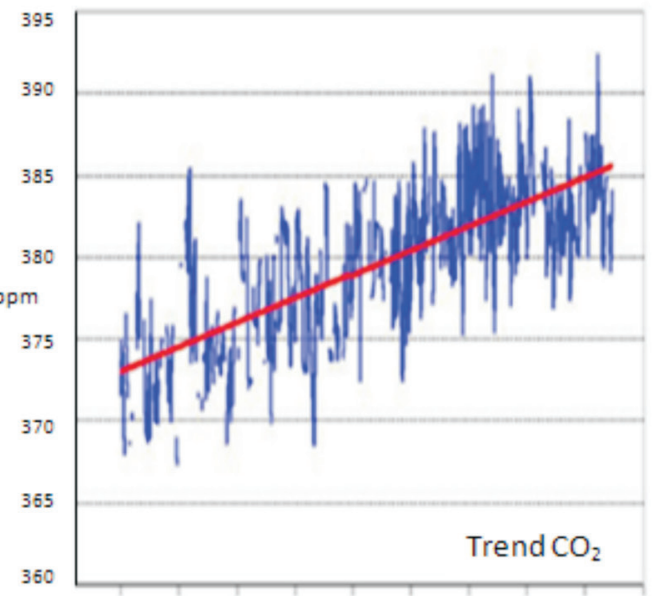

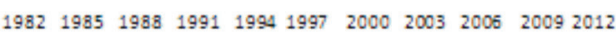

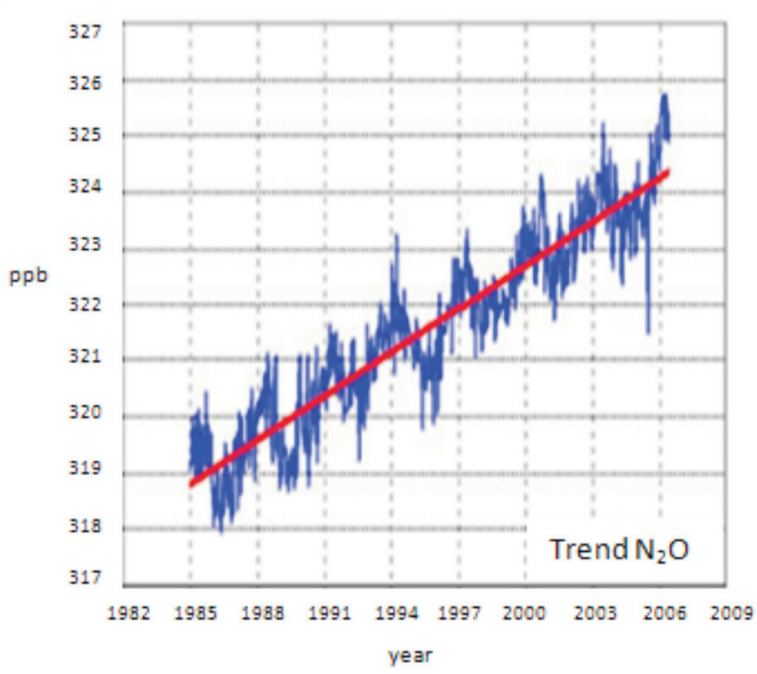

year

Figure 2. Trend of GHG Concentration Changes in Padang

and garden have removed and emitted as $\mathrm{CO}_{2}$. The increasing trend of $\mathrm{N}_{2} \mathrm{O}$ and $\mathrm{NH}_{4}$ concentration due to paddy field, fish pond and husbandry farms converted into developed area (Figure 2).

The increasing trend of GHG concentration had a direct effects on the temperature and the extreme rainfall index in Padang. Trend of extreme temperature indices (TX10p) declined followed by incline of TX90p trend. This condition will make high temperature during day and night (Figure 3).

This is one of indicator that Padang already experiencing global warming. According to the IPCC [2001] that global warming is an indication of climate change has been caused by increasing greenhouse gases in the atmosphere.

The Trend of extreme rainfall occurred in Padang was characterized by an increasing of $\mathrm{Rx} 5$ day compare to Rx1day. It has implication on high rainfall intensity in a relatively short time. The dominant developed area will have an accumulation of surface run off. The high volume of surface-run off will lead to flooding event, flash flooding and landslides [Hermon, 2009; Hermon, 2012]. The high rainfall intensity in relatively short time will caused the declining CWD trend and inclining CDD trend. These conditions will lead unstable hydrological phase in the region.

\section{Conclusion}

Land cover changes into developed area land especially in forests, gardens and shrubs lead into the increasing of GHG concentrations. The increasing of GHG concentration will have direct effect on global warming and climate change. It had been marked that higher temperatures during the day and night and trends of extreme rainfall where high rainfall intensity in relatively short time. 

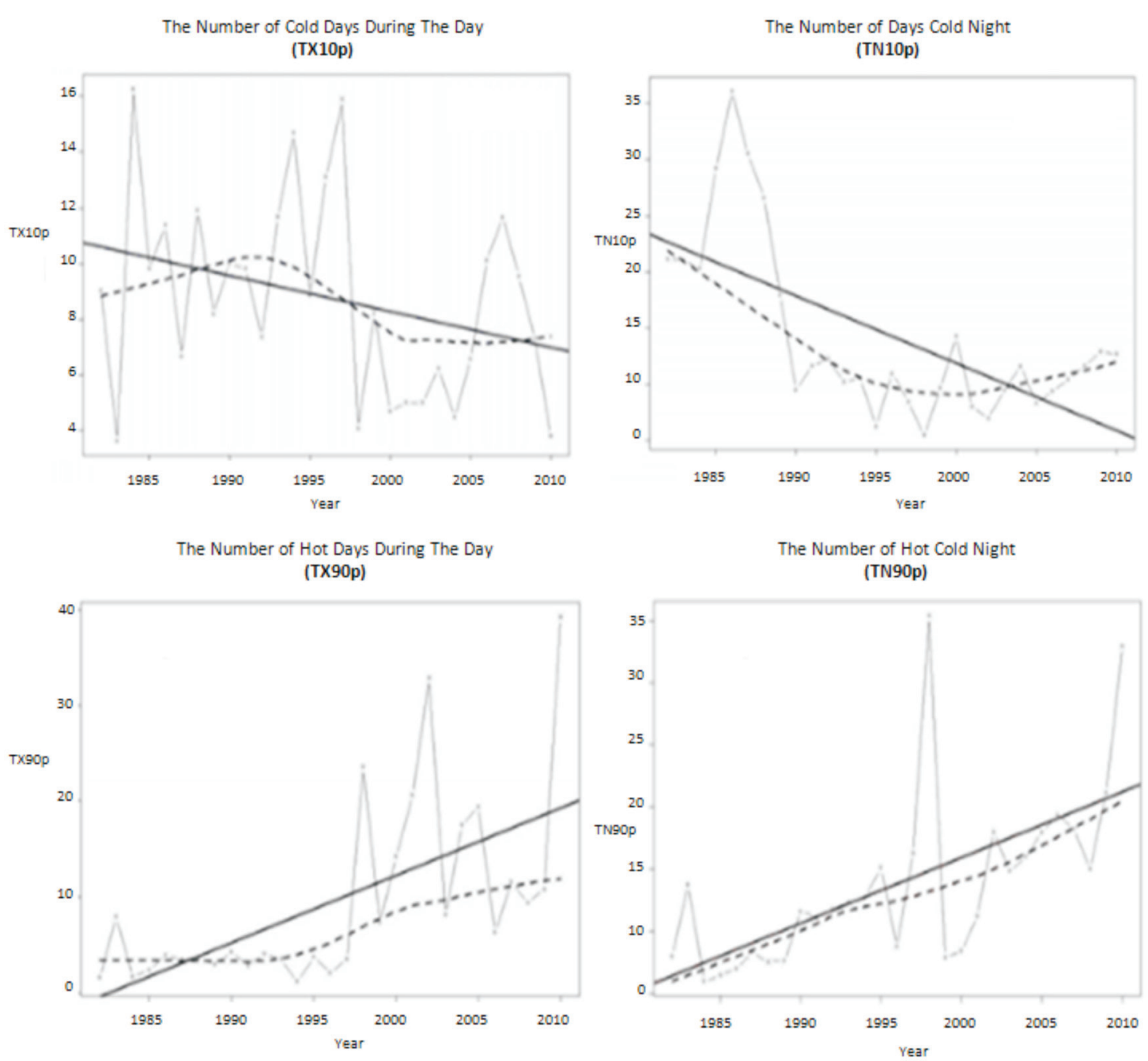

Figure 3. Trend of Extreme Rainfall Index in Padang

\section{References}

BPS Padang (Padang Bureau of Statistics). (1981), Padang in Figures. BPS Padang, West Sumatera Province.

BPS Padang (Padang Bureau of Statistics). (1995), Padang in Figures. BPS Padang, West Sumatera Province.

BPS Padang (Padang Bureau of Statistics). (2006), Padang in Figures. BPS Padang, West Sumatera Province.

Dahroni. (2008), Spatial analysis of change and distribution of slumps in Banjarsari Sub-district Surakarta City 2001-2005 (in bahasa), Forum Geografi 22(1): 85-96.

Departemen Kehutanan and IFCA. (2007), REDDI, Reducing Emissions from Deforestation and Forest Degradation in Indonesia, REDD Methodology and Strategies Summary for Policy Makers, Dephut, Jakarta.

Hairiah, K., \& Rahayu, S. (2007), Measurement of carbon stock in various land use in Bogor (in bahasa). World Agroforestry Centre - ICRAF, SEA
Regional Office, University of Brawijaya, Unibraw. Harun, U.R. (1992), Land use resources dynamics in West Java 1970-1990, Jurnal PWK 3: 48-53.

Hermon, D. (2009), Settlement dynamics and land use planning policies in landslide prone areas in Padang City (in bahasa), P.Hd. Dissertation, IPB, Bogor.

Hermon, D. (2010), Environmental Geography, Global Environmental Change (in bahasa), UNP Press, Padang.

Hermon, D. (2012a), Hydrometeorological disaster mitigation: Flood, landslides, land degradations, ecology, droughts, and local tornadoes (in bahasa), UNP Press, Padang.

Hermon, D. (2012b), Carbon stock dynamic based on land cover changes towards settelment areas in Padang City (in bahasa), Jurnal Forum Geografi (26)1: 45 - 52.

Ketterings, Q.M., Coe R., van-Noordwijk, M., Ambagau Y., Palm C.A. (2001), Reducing Uncertainty in the 
of Allometric Biomass Equation for Predicting Aboveground Tree Biomass in Mixed Secondary Forest, Forest Ecology and Management 146: 199209.

Kustiawan, I. (1997), Agricultural Land conversion issues and implications for spatial planning. case studies; the northern coast of West Java Region (in bahasa), Jurnal PWK 8: 49-60

Lusiana, B., van-Noordwijk, M., Rahayu, S. (2005), Carbon stock in Nunukan-East Kalimantan; Spatial monitoring and modeling (in bahasa), ICRAF, Bogor

Pribadi, D.O., Shiddiq, D., \& Ermyanila, M. (2006), Models of land cover change and it affecting factors (in bahasa), Jurnal Teknologi Lingkungan 7: 35-51.

Ritohardoyo, S. (2007), Coastal rural settlements change in Gunung Kidul, Yogyakarta Special Region in 1996-2003, Forum Geografi 21(1):78 - 92.

WWF. (2008), Deforestation, Forest Degradation, Biodiversity Loss and $\mathrm{CO}_{2}$ Emissions in Riau, Sumatra, Indonesia, One Indonesian Province's Forest and Peat Soil Carbon Loss over a Quarter Century and its Plan for the Future, WWF Indonesia
Technical Report, Jakarta.

Zain, A.F.M. (2002), Distribution, Structure dan Function of Urban Green Space in Southeast Asian Mega-Cities with Special Reference to Jakarta Metropolitan Region (JABOTABEK), P.hD Dissertation, Department of Agricultural and Environmental Biology Graduate School of Agricultural and Life Sciences, The University of Tokyo. 